\title{
HUBUNGAN ANTARA KEIKUTSERTAAN DALAM PROGRAM PENGEMBANGAN DAN KINERJA PROFESIONAL GURU
}

\author{
Rita Aprilianti Rukmana \\ Sultoni \\ Achmad Supriyanto \\ E-mail: rita.aprilianti84@gmail.com \\ Jurusan Administrasi Pendidikan Fakultas Ilmu Pendidikan \\ Universitas Negeri Malang, Jl. Semarang No. 5 Malang 65145
}

\begin{abstract}
This study aims to determine the relationship between participation in the development and professional performanceof vocational high school teacher in Malang City. This research using a quantitative correlation approach. the data was analyzed using Product Moment Pearson correlation. The findings show that: (1) participation teachers in the development program in the category often with the average score of 97.87 ; $(2)$ the performance variables of teacher professional included in the medium category with an average score of 107.48 so included in the enough professional category; and (3) there variable correlation participation in program development and professional performance with a 0.366 correlation value is greater than 0,113 . Thus it can be interpreted as the relationship between Participation in the Program Development and Professional Teachers Performance.
\end{abstract}

Keywords: Development programme, Performance, Profesional teachers

\begin{abstract}
Abstrak: Penelitian ini bertujuan untuk mengetahui hubungan antara keikutsertaan dalam program pengembangan dan kinerja profesional guru SMKN se-Kota Malang. Penelitian ini menggunakan pendekatan kuantitatif korelasional. Data yang terkumpul dianalisis menggunakan uji korelasi Product Moment Pearson. Temuan penelitian menunjukkan, bahwa: (1) keikutsertaan guru dalam program pengembangan dalam kategori sering dengan skor rata-rata sebesar 97,87; (2) variabel kinerja profesional guru masukdalam kategori sedang dengan skor rata-rata 107,48 sehingga termasuk dalam kategori cukup profesional; dan (3) terdapat korelasi variabel keikutsertaan dalam program pengembangan dan kinerja profesional dengan nilai korelasi 0,366 lebih besar dari 0,113.Dengan demikian dapat dimaknai adanya hubungan antara Keikutsertaan dalam Program Pengembangan dan Kinerja Profesional Guru.
\end{abstract}

Kata kunci: Program pengembangan, Kinerja, Profesional guru.

Pendidikan merupakan cara dalam mencerdaskan kehidupan bangsa sesuai dengan Pembukaan Undang-Undang Dasar 1945 alinea keempat dan sebagai tujuan pendidikan nasional. Perkembangan zaman saat ini menuntut adanya sumber daya manusia (SDM) yang berkualitas sehingga mampu bersaing dengan negara lain yang telah maju. Pendidikan mempunyai peranan yang sangat penting dalam menciptakan sumber daya manusia yang berkualitas. Pendidikan yang berkualitas akan berpengaruh pada kemajuan dalam berbagai bidang. Hal tersebut tidak lepas dari peran guru di sekolah sebagai pendidik yang dapat mempengaruhi keluaran (output) peserta didik sehingga diperlukan pengembangan untuk meningkatkan kinerja guru tersebut.

Keberadaan peran dan fungsi guru merupakan salah satu faktor yang sangat signifikan. Guru merupakan bagian terpenting dalam proses belajar mengajar, terutama di jalur pendidikan formal. Oleh sebab itu, setiap upaya peningkatan kualitas pendidikan di tanah air, guru tidak dapat dilepaskan dari berbagai hal yang berkaitan dengan eksistensi mereka.

Pemasalahan guru di Indonesia yang sedang hangat dewasa ini, yaitu tentang kualitas 
atau mutu guru. Kualitas guru Indonesia saat ini disinyalir sangat memprihatinkan. Hasil penelitian Maisyaroh, dkk. (2014:213) menemukan masih ada beberapa permasalahan guru saat implementasi kurikulum 2013 dalam pencapaian standar: isi, proses, kompetensi lulusan, dan penilaian. Bukan itu saja, sebagian guru di Indonesia bahkan dinyatakan tidak layak mengajar. Persentase guru menurut kelayakan mengajar tahun 2002-2003 diberbagai satuan pendidikan antara lain SD negeri yang layak mengajar $21,07 \%$ dan swasta $28,94 \%$. Kelayakan mengajar SMP negeri $54,12 \%$ dan swasta 60,99\%, sedangkan SMA negeri 65,29\% dan swasta $64,73 \%$, serta SMK negeri yang layak mengajar 55,49\% dan swasta 58,26\% (Kasim, 2009).

Realitas semacam ini, pada akhirnya akan mempengaruhi kualitas anak didik yang dihasilkan. Belum lagi masalah seorang guru yang sering mengajar lebih dari satu mata pelajaran (guru kelas) yang tidak jarang bukan merupakan inti dari pengetahuan yang dimilikinya, hal seperti ini tentu saja dapat mengakibatkan proses belajar mengajar menjadi tidak maksimal sehingga kualitas guru tersebut dapat dilihat dari kinerja profesional guru dalam bekerja. Walaupun guru bukan satu-satunya faktor penentu keberhasilan pendidikan, pengajaran tetap merupakan titik sentral pendidikan dan kualifikasi.

Kualitas guru memberikan andil sangat besar pada kualitas pendidikan yang menjadi tanggungjawabnya. Tuntutan profesionalisme guru merupakan hal yang tidak dapat ditawartawar lagi jika suatu bangsa ingin meningkatkan kualitas pendidikan di negeri ini.Menurut Wiyani (2012:71) guru yang profesional adalah orang yang memiliki kemampuan dan keahlian khusus dalam bidang keguruan sehingga ia mampu melakukan tugas dan fungsinya sebagai guru dengan kemampuan maksimal dan profesional yaitu guru yang memiliki kompetensi yang dipersyaratkan untuk melakukan tugas pendidikan dan pembelajaran.

Hal tersebut mengisyaratkan pendidik diharapkan mempunyai pengaruh yang signifikan pada pembentukan SDM(human capital) dalam aspek kognitif, afektif maupun keterampilan, dan juga baik dalam aspek fisik, mental maupun spiritual. Penjelasan ini menuntut kualitas penyelenggaraan pendidikan yang baik serta pendidik yang profesional agar kualitas hasil pendidikan dapat benar-benar berperan secara optimal dalam kehidupan masyarakat serta pendidik dituntut untuk selalu memperbaiki, mengembangkan diri dalam membangun dunia pendidikan. Selain itu, upaya meningkatkan kinerja adalah memberikan pengembangan maupun pelatihan agar sumber daya manusia yang ada pada suatu sekolah dapat ditingkatkan kemampuannya, dipertahankan kondisinya dan keberadaannya. Mempertahankan kondisi sumber daya manusia tersebut berarti dapat mencegah keluarnya mereka dari sekolah sekaligus dapat memberikan kontribusi secara maksimal untuk sekolah.

Pengembangan pendidik dirasa semakin penting manfaatnya karena tuntutan pekerjaan atau jabatan sebagai kemajuan teknologi dan semakin sadarnya masyarakat akan pentingnya pendidikan. Tujuan kegiatan pengembangan adalah untuk meningkatkan mutu guru agar guru lebih profesional dalam pelaksanaan tugas dan tanggung jawabnya. Minarti (2011:139) menyatakan pengembangan tenaga pendidik dimaksudkan untuk meningkatkan kemampuan dan kecakapan tenaga pendidik menjadi lebih produktif. Usaha mengembangkan dan meningkatkan kemampuan pendidik, biasanya dilakukan latihan-latihan tertentu sesuai dengan arah kemampuan yang telah dimiliki atau searah dengan bidang kerja dari masing-masing pendidik yang bersangkutan. Sasaran utama sebagian besar dari program-program pengembangan ialah meningkatkan prestasi individu dan organisasi dan mempersiapkan guru-guru pilihan untuk memangku pekerjaan atau jabatan yang lebih tinggi (Manullang, 2011:41).

Hasil penelitian Koswara dkk. (2009:5) menyebutkan bahwa sertifikasi memiliki pengaruh yang rendah terhadap profesionalisme dan mutu pembelajaran, karena masih ada sesuatu yang salah pada sertifikasi terkait dengan desain atau sistem, proses, atau hasil yang ditargetkan. Oleh sebab itu pembinaan terhadap pendidik secara mandiri perlu dilaksanakan karena adanya program dan kurikulum sekolah yang selalu dinamis dan berkembang sesuai dengan perkembangan ilmu pengetahuan, masyarakat, dan kebudayaan. Pembinaan dan perbaikan mutu pendidikan tidak mungkin berhasil tanpa disertai dengan pembinaan dan perbaikan mutu 
pengetahuan pendidik.

Peranan pendidik yang ada di semua jenjang pendidikan termasuk Sekolah Menengah Kejuruan Negeri (SMKN) di Kota Malang sangat berpengaruh bagi peserta didik. Sehubungan dengan tugasnya sehari-hari yakni mengajar maka diharapkan pendidik memiliki pengetahuan, kemampuan dan keterampilan. Sebab dalam Undang-undang Sistem Pendidikan Nasional Nomor 20 Tahun 2003 Pasal 15 menjelaskan bahwa pendidikan kejuruan adalah pendidikan menengah yang mempersiapkan peserta didik terutama untuk bekerja dalam bidang tertentu. Dapat ditarik kesimpulan bahwa setiap jenjang pendidikan kejuruan dibutuhkan guru kompeten yang menjadi pemegang peran terpenting dalam mewujudkan keluaran peserta didik yang terampil dan siap bekerja di dunia usaha maupun dunia industri.

Kinerja merupakan suatu hasil kerja yang dihasilkan oleh seseorang untuk mencapai tujuan yang diharapkan dalam melaksanakan tugas sesuai dengan tanggung jawab yang diberikan kepadanya. Pengertian unjuk kerja ini menurut Wahyuni \& Ulfatin (2016:174) dapat dimengerti melalui perilaku, hasil, dan keefektifan organisasi. Perilaku mengacu kegiatan-kegiatan dalam mencapai tujuan tertentu. Perilaku individu memberikan hasil terhadap kerja yang hasilnya bersifat obyektif maupun subyektif. Sementaraitu, Uno \& Lamatenggo (2012:69) menyatakan bahwa kinerja merupakan gambaran hasil kerja yang dilakukan seseorang atau dengan kata lain kinerja adalah unjuk kerja seseorang. Berdasarkan dari pendapat tersebut maka peneliti menyimpulkan bahwa kinerja guru adalah hasil kerja yang dapat dicapai seorang guru dalam melaksanakan tugas dan tanggungjawabnya sesuai dengan harapan dan tujuan yang telah disepakati bersama.

Kinerja guru sangat diperlukan apalagi untuk mewujudkan kedisiplinan peserta didik dalam ruang lingkup pendidikan. Selain itu, guru juga berperan penting untuk melatih peserta didik meningkatkan kedisiplinan di kelas maupun di sekolah. Tujuan kinerja menurut Mangkunegara (2006:10) yaitu untuk memperbaiki atau meningkatkan kinerja dalam suatu organisasi.Untukmendapatkankinerja guru yang optimal, maka sangat diperlukan adanya kegiatan pengembangan guru.Sikula (2011:41)berpendapat, bahwa "development, in reference to staffing and personnel matters, is a long term educational process utilizing a systematic and organized procedure by which managerial personnel learn conceptual and theoretical knowledge for general purpose." SedangkanSuwatno dan Priansa (2011:105) menjelaskan bahwa "pengembangan guru adalah aktivitas memelihara dan meningkatkan kompetensi guru guna mencapai efektivitas organisasi."

Upaya untuk mengembangkan dan meningkatkan kinerja guru pada dasarnya merupakan suatu kebutuhan sekolah yang tidak pernah berakhir, ini disebabkan pengembangan dan peningkatan kinerja tidak hanya dilakukan jika terjadi kesenjangan antara kinerja aktual dengan kinerja yang diharapkan, tapi juga pengembangan dan peningkatan tersebut harus tetap dilakukan meskipun tidak terjadi kesenjangan, sebab perubahan lingkungan eksternal sekolah yang sangat cepat dewasa ini akan mendorong pada meningkatnya tuntutan yang lebih tinggi pada sekolah.

Oleh karena itu, diperlukan strategi dalampengembangan dan peningkatan kinerja guru yang berkesinambungan, termasuk di dalamnya meliputi pendidikan dan pelatihan yang perlu mendapat perhatian dalam mengembangkan dan meningkatkan kinerja. Maka strategi pengembangan ke arah sekolah menjadi amat penting agar pengembangan dan peningkatan kinerja guru menjadi suatu bagian yang tak terpisahkan dari sekolah. Danim (2010:42) memaparkan "beberapa strategi pengembangan antara lain yaitu diskusi masalah-masalah pendidikan, seminar, workshop, penulisan buku bahan ajar, pembuatan media pembelajaran dan pembuatan karya teknologi atau karya seni." Direktorat Jenderal Pendidikan Dasar dan Menengah Departemen Pendidikan Nasional (dalam Mulyana, 2010:70) menyebutkan beberapa alternatif program pengembangan profesionalisme guru. Program tersebut antara lain: a) Kualifikasi Pendidikan Guru; b) Program Penyetaraan; c) Program Pelatihan Terintegrasi Berbasis Kompetensi; d) Program Supervisi Pendidikan; e) Program Pemberdayaan KKG dan MGMP; f) Studi Banding dan g) Mengikuti berita aktual dari media.

Tujuan dalam penelitian ini yaitu: 
mendeskripsikan frekuensi dan kualitas keikutsertaan guru SMKN se-Kota Malang dalam mengikuti program pengembangan; 2) mendeskripsikan kualitas kinerja profesional guru SMKN se-Kota Malang; dan 3) mengetahui hubungan keikutsertaan dalam program pengembangan dengan kinerja profesional guru SMKN se-Kota Malang.

\section{METODE}

Penelitian ini menggunakan pendekatan kuantitatif dengan menggunakan model korelasi Product Moment Pearson.Penelitian dilakukan di SMKN se-Kota Malang yang terdiri dari 13 Sekolah. Populasi dalam penelitian ini adalah guru PNS SMKN se-Kota Malang yang berjumlah 604 guru dibulatkan menjadi 600 guru, maka dengan formula Slovin mendapatkan sampel 234 guru. Instrumen yang digunakan untuk mengumpulkan data dalam penelitian ini adalah kuesioner atau angket. Instrumen yang digunakan untuk mengumpulkan data dalam penelitian ini adalah kuesioner atau angket. Penghitungan validitas butir angket dalam penelitian ini menggunakan program $P A S W$ Statistics 16. Rumus untuk uji reliabilitas dalam penelitian ini menggunakan formula Alpha Cronbach.

Pengumpulan data dalam penelitian ini dilakukan melalui beberapa tahapan: (1) tahap persiapan; (2) tahap pelaksanaan; (3) tahap pengolahan data. dan (4) tahap pelaporan. Analisis data menggunakan analisis deskriptif yaitu menentukan kualifikasi terlebih dahulu. Tujuan dalam penentuan kualifikasi tersebut untuk mengetahui interval nilai tiap variabel yang terdiri dari tingkat tinggi, sedang, dan rendah. Dilanjutkan dengan analisis korelasi dengan maksud untuk melihat hubungan antara satu variabel dengan variabel lainnya dengan menggunakan teknik korelasi Product Moment Pearson.

\section{HASIL}

$\begin{array}{crcr}\text { Hasil penelitian meliputi } & \text { distribusi } \\ \text { keikutsertaan guru } & \text { dalam program }\end{array}$ pengembangan, tingkat kinerja profesional guru, dan hubungan antara keikutsertaan dalam program pengembangan dan kinerja profesional guru.
Variabel keikutsertaan dalam program pengembangan dijabarkan menjadi 6 sub variabel dan 17 indikator yang dijadikan pernyataan dalam angket sejumlah 30 butir. Setiap butir dikategorikan menjadi 3 kategori jawaban. Berdasarkan rincian pada jabaran variabel, diperoleh 30 item pernyataan yang akan dianalisis. Hasil variabel keikutsertaan dalam program pengembangan menunjukkanistribusi variabel keikutsertaan guru dalam program pengembangan diketahui memiliki skor rata-rata sebesar97,87sehingga kriteria mengikuti program pengembangan termasuk dalam tingkat sering. Sementaraituuntukvariabel kinerja profesional guru rata-rata 107,48 sehingga termasuk dalam kategori cukup profesional.

Setelah mendeskripsikan data, dilanjutkan dengan mengadakan pengujian hipotesis. Hasil analisis keikutsertaan dalam program pengembangan dan kinerja profesional guru SMKN se-kota Malang menunjukkan ada hubungan yang signifikan dengan rhitung $\Rightarrow$ rtabel $(0,366>0,113)$. Hal ini berarti hipotesis nol (H0) ditolak dan menerima hipotesis 1 (H1), maka nilai rtabel $=0,366$ dinyatakan memiliki hubungan dengan kategori rendah antara variabel keikutsertaan dalam program pengembangan dan kinerja profesional guru, sehingga diketahui keikutsertaan dalam program pengembangan masuk pada kategori seringdengan persentase sebesar 78,20\%, dan kinerja profesional masuk pada kategori cukup profesional dengan persentase $59,50 \%$. Korelasi variabel keikutsertaan dalam program pengembangan dan kinerja profesional dengan nilai korelasi 0,366 lebih besar dari 0,113 . Pengujian hipotesis yang diperoleh menolak $\mathrm{H} 0$ dan menerima $\mathrm{H} 1$ yang diartikan menerima adanya hubungan antar variabel.

\section{PEMBAHASAN}

Berdasarkan analisis penelitian tentang keikutsertaan guru dalam program pengembangan, diperoleh hasil penelitian bahwa frekuensi keikutsertaan menunjukkan pada tingkat kategori sering, sedangkan kualitas mengikuti masuk pada kategori sedang. Frekuensi masuk pada kategori sering artinya guru intensitas guru mengikuti sering terlibat dalam kegiatan program pengembangan. 
Selanjutnya kualitas dikategorikan sedang yang artinya guru mengikuti program pengembangan lebih dari 50\% acara, memiliki pemahaman yang cukup dan menerapkan pengetahuan tersebut dalam melaksanakan tugasnya.

Sesuai dengan teori yang menyatakan mengenai program pengembangan oleh Suwatno \& Priansa (2011:105) bahwa pengembangan guru adalah aktivitas memelihara dan meningkatkan kompetensi guru guna mencapai efektivitas organisasi. Tingkat frekuensi keikutsertaan guru SMKN se-Kota Malang dalam program pengembangan menunjukkan kategori sering berarti guru SMKN se-Kota Malang memiliki sikap usaha untuk memelihara dan mempertahankan kompetensi. Seorang guru yang sering mengikuti program pengembangan akan dapat memenuhi kualifikasi akademik yang berlaku secara nasional yaitu kualifikasi minimal pendidikan guru dengan menempuh S1 atau D4 melalui kuliah seperti yang telah dicantumkan dalam sub variabel program pengembangan.

Guru dikatakan sering mengikuti program pengembangan dengan kualitas sedang berarti kompetensi guru meningkat untuk mencapai efektivitas organisasi dan tanggungjawabnya antara lain dapat dilihat pada kegiatan pembelajaran. Program pengembangan sesuai kondisi di lapangan berupa program pendidikan dan pelatihan, sesuai dengan pendapat Flippo (2006) bahwa pengembangan merupakan suatu proses dari pelatihan untuk meningkatkan keahlian serta pengetahuan untuk melakukan pekerjaan tertentu. Adapun pendidikan yang berkaitan dengan perluasan pengetahuan umum, tenaga operasional, dan para manajer.

Rincian pernyataan yang tercantum dalam angket variabel program pengembangan meliputi kesesuaian materi, keahlian pemateri, dan tujuan program pengembangan.Hal tersebut dapat digunakan untuk mengetahui seberapa tinggi kualitas guru dalam mengikuti program pengembangan. Komponen pelatihan memiliki tujuan yang jelas dan dapat diukur, pelatih harus ahlinya, materi dan metode yang sesuai, serta peserta pelatihan yang memenuhi syarat. Oleh sebab itu pelatihan kinerja pegawai harus dilakukan dalam beberapa tahap sesuai hasil penelitian Anitawati \& Wiyono (2011:223) bahwa perencanaan dari identifikasi kebutuhan, komponen pelatihan dan rancangan program; pengorganisasian penyelenggaraan pelatihan.

kerja; pelaksanaan/ pelatihan; dan evaluasi

Selain itu guru yang sering dengan kualitas sedang dalam mengikuti program pengembangan Musyawarah Guru Mata Pelajaran (MGMP) maka kualitas guru mulai dari penguasaan model pembelajaran, strategi pembelajaran sampai pendalaman materi yang diampunya dapat meningkat. Program pengembangan studi banding, guru bisa melihat dan berdiskusi tentang manajemen sekolah, strategi pembinaan peserta didik, desain ruangan, penataan kurikulum, dan lain-lainnya. Bagi guru, studi banding bermanfaat untuk melepas penat serta bisa menambah ilmu secara langsung. Dengan mengunjungi sekolah yang lebih baik, guru dapat lebih termotivasi untuk melakukan pembenahan di sekolahnya. Hal tersebut sejalan dengan pendapat Suwatno \& Priansa (2011:105) tujuan yang ingin dicapai dari pengembangan guru meliputi produktivitas kerja, efisiensi, pelayanan, moral guru, karier, kepemimpinan, dan kompensasi.

Responden yang mengisi angket penelitian yaitu guru PNS, baik guru PNS yang baru ataupun yang lama sesuai hasil penelitian Sari, Imron, \& Setyadin (2013:175) bahwa tingkat etos kerja guru tetap dalam kategori tinggi karena mereka memiliki semngat kerja tinggi. Guru baru biasanya hanya mengetahui teori saja tapi masih dangkal dalam pengalaman kerja karena apa yang mereka dapat dari bangku pendidikan hanyalah teori dan kurang mengerti akan seluk beluk dunia kerja. Guru mengikuti pengembangan tersebut maka secara cepat mereka dapat menyesuaikan diri dengan dunia pekerjaan yang mereka hadapi, sedangkan pengembangan guru lama dilaksanakan karena tuntutan pekerjaan, jabatan, metode kerja yang diperbaharui dan juga untuk persiapan promosi. Sehingga dapat ditarik kesimpulan bahwa responden baik guru baru dan guru lama setelah aktif mengikuti program pengembangan dapat meningkatkan produktivitas dan karier guru.

Hasil penelitian variabel keikutsertaan dalam program pengembangan ditetapkan aktif mengikuti dengan kualitas sedang menunjukkan bahwa guru SMKN se-kota Malang adalah guru yang peduli terhadap perkembangan zaman, memelihara kompetensi, meningkatkan kinerja ataupun produktivitas, dan memiliki sikap 
mengusahakan untuk menjadikan kegiatan pembelajaran efektif dan efisien sehingga dalam perkembangan ilmu pengetahuan dan teknologi yang semakin pesat ini guru SMKN se-Kota Malang tetap menjaga kualitas diri dan meningkatkan kinerja melalui sering mengikuti program pengembangan pendidikan maupun pelatihan, baik di dalam maupun di luar sekolah.

Hasil penelitian menunjukkan bahwa kuantitas kinerja berada pada presentase 59\% dengan kualitas termasuk pada tingkat sedang yang berarti profesional. Uno \&Lamatenggo (2012:69) menjelaskan kinerja merupakan gambaran hasil kerja yang dilakukan seseorang atau dengan kata lain kinerja adalah unjuk kerja seseorang. Selain itu hal tersebut juga diungkapkan oleh Ardhiansyah (2010:2) bahwa kinerja guru adalah hasil kerja yang dapat dicapai oleh seorang guru di lembaga pendidikan atau madrasah sesuai dengan tugas dan tanggung jawabnya dalam mencapai tujuan pendidikan. Maka dapat diketahui gambaran kinerja dari analisis hasil penelitian masuk kategori profesional pada tingkat sedang tersebut menunjukkan bahwa guru SMKN se-kota Malang guru memiliki kompetensi keguruan yang cukup.

Kompetensi keguruan itu tampak pada kemampuannya menerapkan sejumlah konsep, asas kerja sebagai guru, mampu mendemonstrasikan sjumlah strategi maupun pendekatan pengajaran yang menarik dan interaktif, disiplin, jujur dan konsisten. Sesuai dengan keputusan Undang-Undang Nomor 14 Tahun 2005 Bab II Pasal 2 Ayat (1) yang menjelaskan bahwa guru mempunyai kedudukan sebagai tenaga profesional pada jenjang pendidikan dasar, menengah, dan pendidikan anak usia dini pada jalur pendidikan formal, yang diangkat sesuai dengan peraturan perundangundangan.

Penelitian mengenai kinerja adalah untuk tolak ukur dalam kegiatan pembelajaran dan sebagainya yang berhubungan dengan pendidikan. Kinerja guru sangat diperlukan apalagi untuk mewujudkan kedisiplinan peserta didik dalam ruang lingkup pendidikan. Selain itu, guru juga berperan penting untuk melatih peserta didik meningkatkan kedisiplinan di kelas maupun di sekolah. Sesuai dengan pendapat Mangkunegara (2006:10) yaitu untuk memperbaiki atau meningkatkan kinerja dalam suatu organisasi.

Kinerja guru masuk kategori profesional dalam tingkat sedang, hal ini berarti guru SMKN se-Kota Malang mampu melakukan kegiatan pembelajaran dengan baik mulai dari perencanaan program kegiatan pembelajaran, pelaksanaan kegiatan pembelajaran, dan evaluasi atau penilaian pembelajaran. Guru yang dianggap profesional dan terjamin kualitasnya diyakini mampu melaksanakan tugas dan fungsinya dengan baik. Penjaminan mutu guru perlu dilakukan dari waktu ke waktu demi terselenggaranya layanan pembelajaran yang berkualitas.

Program pengembangan merupakan hal yang dapat mempengaruhi hasil seseorang dalam bekerja dalam suatu sekolah. Hasil penelitian menyimpulkan ada hubungan antara keikutsertaan dalam program pengembangan dan kinerja profesional guru SMKN se-Kota Malang pada kategori rendah. Hal ini sesuai pendapat Saputra (2014:1) yang menjelaskan mengenai pengembangan kinerja pegawai perlu dilakukan sekolah yang dapat mengkondisikan dan mendorong terjadinya proses pengembangan dan peningkatan kinerja individu pegawai. Strategi diperlukan agar arah serta target kinerja yang ingin dicapai dan dikembangkan menjadi bagian yang terintegrasi dengan tujuan sekolah.

Upaya untuk mengembangkan dan meningkatkan kinerja pegawai pada dasarnya merupakan suatu kebutuhan sekolah yang tidak pernah berakhir, ini disebabkan pengembangan dan peningkatan kinerja tidak hanya dilakukan jika terjadi kesenjangan antara kinerja aktual dengan kinerja yang diharapkan, tapi juga pengembangan dan peningkatan tersebut harus tetap dilakukan meskipun tidak terjadi kesenjangan, sebab perubahan lingkungan eksternal sekolah yang sangat cepat dewasa ini akan mendorong pada meningkatnya tuntutan yang lebih tinggi pada sekolah.Sejalan dengan ini adalah temuan penelitian Sobri (2013:9) yaitu peran kepala sekolah sebagai supervisor adalah meningkatkan keberhasilan keseluruhan program pembelajaran sekolah dengan membantu guru memecahkan pembelajaran di kelas sehingga kemampuan guru dapat berkembang

Kondisi kategori rendah dapat disebabkan beberapa faktor lain seperti hasil penelitian Danarto (2008) kebanyakan mempersepsikan pembinaan pada kategori tinggi, kinerja para 
guru berada pada kategori rendah. Penelitian Triono (2008) yang berjudul Hubungan Motivasi kerja dengan Kinerja Guru Sekolah Menengah Atas Negeri (SMAN) di Kecamatan Jombang. Hasil penelitian menunjukkan bahwa Kondisi tingkat motivasi kerja guru dan kinerja guru SMAN di Kecamatan Jombang adalah sangat tinggi,serta terdapat hubungan yang signifikan antara motivasi kerja guru dengan kinerja guru SMAN di kecamatan Jombang.

Faktor-faktor tersebut dapat menyebabkan rendahnya hubungan karena program pengembangan merupakan salah satu bagian yang penting, bukan seluruh bagian yang penting. Hal ini juga dikarenakan peneliti memilih program pengembangan untuk mengetahui hubungannya dengan kinerja profesional yang belum pernah diteliti di SMKN se-Kota Malang. Selain itu karena keterbatasan mulai dari waktu, biaya, dan tenaga. Adapun pendapat Sedarmayanti (2008) bahwa kinerja individu biasanya dipengaruhi oleh faktor-faktor harapan mengenai imbalan, dorongan, kemampuan, kebutuhan dan fisik, persepsi terhadap tugas, persepsi terhadap imbalan dan kepuasan kerja.Serta beberapa faktor yang mempengaruhi antara lain sikap mental, pendidikan, keterampilan, manajemen kepemimpinan, gaji, jaminan sosial, iklim kerja, sarana prasarana, teknologi, dan kesempatan berprestasi.

Dapat disimpulkan kinerja profesional dimungkinkan tidak hanya dipengaruhi oleh program pengembangan saja, sehingga hubungan kinerja profesional dan program pengembangan masuk dalam kategori rendah.

\section{KESIMPULAN DAN SARAN}

\section{Kesimpulan}

Kajian produk dalam subbab ini difokuskan terhKKesimpulan yang diperoleh: (1) Frekuensi keikutsertaan guru SMKN se-Kota Malang dalam program pengembangan masuk dalam tingkat sering sedangkan kualitas keikutsertaan masuk pada kategori sedang. Tingkat sering berarti guru memiliki intensitas yang tinggi dalam mengikuti kegiatan program pengembangan, sedangkan kualitas sedang berarti guru cukup memahami materi, kegiatan ataupun penugasan dalam program pengembangan. (2) Kinerja profesional guru SMKN se-Kota Malang termasuk dalam kategori cukup profesional. Kategori profesional memiliki makna guru SMKN se-Kota Malang mampu melakukan kegiatan pembelajaran dengan baik mulai dari perencanaan program kegiatan pembelajaran, pelaksanaan kegiatan pembelajaran, dan evaluasi atau penilaian pembelajaran. Guru berarti telah melakukan sesuatu sebagai pekerjaan pokok sebagai profesi dan bukan sebagai pengisi waktu. (3) Terdapat hubungan yang signifikan antara keikutsertaan dalam program pengembangan dan kinerja profesional guru SMKN se-Kota Malang pada kategori rendah.

\section{Saran}

Saran diberikan kepada: (1) kepala sekolah, membuat jadwal pengembangan dan pengawasan secara berkala untuk mempertahankan frekuensi keikutsertaan guru mengikuti kegiatan. Selain itu kepala sekolah perlu menghimbau guru saat mengikuti program pengembangan agar lebih serius, memperhatikan dengan seksama, dan mengikuti acara sampai selesai sehingga dapat meningkatkan kualitas pemahaman dan dapat mengimplementasikannya; (2) guru hendaknya memiliki keinginan yang kuat dan kesadaran dari dalam diri untuk mengikuti program pengembangan dengan sungguh-sungguh agar kualitas pemahaman menjadi maksimal dan dalam mengimplementasikan hasil dari kegiatan dapat memberikan pengaruh yang baik untuk peserta didik; (3) mahasiswa Administrasi Pendidikan, dilanjutkan untuk penelitian dalam lingkup manajemen sumber daya manusia khususnya peningkatan kinerja guru ataupun pegawai di sekolah ataupun di intansi pendidikan lain; dan (4) peneliti lain, dapat dilanjutkan untuk meneliti faktor-faktor lain yang dimungkinkan mempengaruhi variabel kinerja profesional guru. Mengukur kinerja profesional menggunakan instrumen lain (selain angket) misalnya tes, portofolio, observasi, dan penilaian sejawat.

\section{DAFTAR RUJUKAN}

Agung, I., Nadiroh \& Rumtini. 2011. Pendidikan Anitawati, A.D., \& Wiyono, B.B. 2011. Peningkatan kinerja Pegawai dalam Menyelenggarakan Pelatihan. Manajemen Pendidikan. 23(3): 233-233. 
Ardiansyah, A. 2010. Pengertian Kinerja Guru, (Online),

(http://pengertian_kinerja_guru.blogspot.com), diakses 19 Januari 2015.

Danarto, B.K. 2008. Hubungan antara Teknik Pembinaan dengan Kinerja Staf Administrasi pada Dinas Pendidikan dan Kebudayaan Kabupaten Wonogiri Propinsi Jawa Tengah. Skripsi tidak diterbitkan. Malang: Fakultas Ilmu Pendidikan Universitas Negeri Malang.

Danim, S. 2010. Karya Tulis Inovatif: Sebuah Pengembangan Profesional. Bandung: Rosdakarya.

Flippo, E.B. 2006. Manajemen Personalia. Jakarta: Erlangga.

Kasim, M. 2009. Makalah Masalah Pendidikan di Indonesia, (Online), (https://meilanikasim. wordpress.com/2009/03/08/makalah-masalahpendidikan-di-indonesia/), diakses 20 Januari 2016.

Koswara, D.D., Suryana, A., \& Triatna, C. 2009. Studi Dampak Program Sertifikasi Guru Terhadap Peningkatan Profesionalisme dan Mutu. Jurnal Ilmu Pendidikan, (Online), 3 (1):5, (http://upi. edu.com), diakses 22 Maret 2013.

Maisyaroh. Zulkarnain, W., Setyowati, A.J., \& Mahanal, S. 2014. Masalah Guru dalam Implementasi Kurikulum 2013 dan Kerangka Model Supervisi Pengajaran. Manajemen Pendidikan. 24(3): 213-220.

Mangkunegara, A.A.A.P. 2006. Evaluasi Kinerja SDM. Bandung: Refika Aditama.

Manullang, M. 2011. Manajemen Sumber Daya Manusia. Yogyakarta: BPFE.

Minarti, S. 2011. Manajemen Sekolah: Mengelola embaga Pendidikan secara Mandiri. Yogyakarta: Ar-Ruzz Media.

Mulyana. A.Z. 2010. Rahasia Menjadi Guru Yang Hebat. Jakarta: Gramedia

Musarofah. 2008. Kinerja Guru di MTs Al-Wathoniyah 1 Cilungup, Duren Sawit- Jakarta Timur (Pdf), (Online), (http://www.riwayat.web.id), diakses 19 Januari 2015.

Saputra, U. 2014. Pengembangan Kinerja Guru, (Online),(https://uharsputra.wordpress.com/ supervision/pkb-guru/pengembangan-kinerjaguru/), diakses 1 April 2015.

Sari, T.E., Imron, A., \& Setyadin, B. 2013. Perbedaan Tingkat Etos Kerja antara Guru Tetap dan Guru Tidak Tetap. Manajemen Pendidikan. 24(2): 175180.

Sedarmayanti. 2008. Manajemen Sumber Daya Manusia dan Produktivitas Kerja. Bandung: CV Mandar Maju.
Sikula, A.E. 2011. Manajemen Sumber Daya Manusia. Bandung: Erlangga.

Sobri, A.Y. 2013. Pembinaan Profesionalisme Guru dalam Meningkatkan Kualitas Pembelajaran. Manajemen Pendidikan. 24(1): 9-20.

Suwatno \& Priansa, D.J. 2011. Manajemen SDM dalam Organisasi Publik dan Bisnis. Bandung: Alfabeta.

Triono, D. 2008. Hubungan Motivasi kerja dengan Kinerja Guru Sekolah Menengah Atas Negeri (SMAN) di Kecamatan Jombang. Skripsi tidak diterbitkan. Malang: Fakultas Ilmu Pendidikan Universitas Negeri Malang.

Undang-Undang Republik Indonesia Nomor 14 Tahun 2005 tentang Guru dan Dosen. Pendidikan Tinggi (sindiker.dikti.go.id/dok/UU/ UUNo142005(Guru\%20\&\%20Dosen).pdf), diakses 10 januari 2016.

Undang-Undang Republik Indonesia Nomor 20 Tahun 2003 tentang Sistem Pendidikan Nasional. 2010. Bandung: Citra Umbara.

Uno, H.B. \& Lamatenggo, N. 2012. Teori Kinerja dan Pengukurannya. Jakarta: Bumi Aksara.

Wahyuni, R. \& Ulfatin, N. 2016. Persepsi Guru Terhadap Budaya Sekolah dalam Hubungannya dengan Kinerja Guru di SMP Negeri. Manajemen Pendidikan. 25(2): 169-175.

Wiyani, N. A. 2012. Teacherpreneurship: Gagasan \& Upaya Menumbuh-kembangkan Jiwa Kewirausahaan Guru. Jogjakarta: Ar-Ruzz Media.

Wiyono, B. B. 2007. Metodologi Penelitian (Pendekatan Kuantitatif, Kualitatif, dan Action Research). Malang: Departemen Pendidikan Nasional Universitas Negeri Malang Fakultas Ilmu Pendidikan. 